\title{
ANALISA PENGOPERASIAN 1 CWP DAN 2 CWP PADA COOLING WATER SYSTEM PLTU ASAM ASAM UNIT 4
}

\author{
Juni Eko Hartanto1), Mastiadi Tamjidillah' ${ }^{2)}$ \\ ${ }^{1,2}$ Program Studi Teknik Mesin \\ Fakultas Teknik Universitas Lambung Mangkurat \\ JL. Akhmad Yani Km. 36 Banjarbaru, Kalimantan Selatan,70714 \\ e-mail: junieko60@gmail.com
}

\begin{abstract}
Electric power is used to support daily life, therefore electrical energy must be continually developed considering the increasing need for this energy. Therefore it is necessary to do preventive, corrective maintenance and efforts to optimize the generating unit such as savings in the production process, one of which is by analyzing the operation of a Circulating Water Pump CWP at the Unit 4 Acid-Acid Power Plant. The formulation of the problem in this study is that in the manufacturer's design for $65 \mathrm{MW}$ full load 2 CWP pumps are needed, this can be seen from the pump specification data, but in fact with only a Circulating Water Pump CWP can produce a full load of $65 \mathrm{MW}$.
\end{abstract}

Keywords : Tara Calor, Thermal Efficiency, Net Power and Own Use, Vacuum Pressure and Main Steam Flow

\section{PENDAHULUAN}

Tenaga listrik digunakan untuk menunjang kehidupan sehari-hari. Energi listrik ini harus terus menerus dikembangkan mengingat semakin meningkatnya kebutuhan masyarakat terhadap energi ini. Oleh karena itu, perlu dilakukan preventif, korektif maintenance serta usaha usaha untuk mengoptimalkan unit pembangkit seperti penghematan pada proses produksi, salah satunya dengan menganalisa pengoperasian satu pompa CWP pada PLTU Asam-Asam Unit 4.

Analisa pengoperasian 1 CWP DAN 2 CWP ini disusun untuk mengambil pertimbangan dalam memilih mana pola operasi yang paling tepat dalam sistem Cooling Water Unit 4. Pada analisa ini pertimbangan diambil berdasarkan perbandingan parameter operasi dan parameter turunan. Dengan dimatikannya 1 pompa CWP pada unit, PLTU Asam Asam tetap dapat beroperasi pada beban optimal. Hal ini berdampak langsung pada tara kalor, di mana tara kalor Unit 4 mengalami penurunan. Turunnya tara kalor ini tentu saja menarik perhatian, karena tara kalor yang rendah menjadi lebih baik pada sisi kinerja pembangkit. Namun, mengingat unit ini dirancang dengan dua CWP beroperasi pada daya mampu optimal, dikhawatirkan ada efek samping terhadap unit dalam jangka panjang. Karena itulah, dilakukan analisa mengenai hal ini setelah sebelumnya diambil terlebih dahulu data-data operasi.

\section{Sistem Air Pendingin Utama}

Air tawar yang berasal dari sungai atau danau dipompakan sebagai makeup cooling tower setelah sebelumnya dilakukan treatment (sedimentasi dan koagulasi) terlebih dahulu. Air tersebut digunakan untuk mendinginkan prosesproses di dalam pabrik. Air pendingin yang telah panas kemudian didinginkan di cooling tower untuk kemudian disirkulasikan kembali ke dalam pabrik. Untuk menjaga kualitas air, misalnya agar tidak terdapat algae/bacteria dan pengendapan (scaling), maka perlu diinjeksikan beberapa jenis chemicals tertentu. Kualitas air juga dijaga melalui mekanisme make-up dan blow-down. 
Sistem ini banyak digunakan oleh pabrik yang berada dekat dengan sumber air tawar atau jauh dari laut. Spesifikasi material untuk peralatan yang menggunakan air tawar tidak perlu sebagus peralatan yang menggunakan air laut, karena air tawar lebih tidak korosif dibandingkan dengan air laut. Open recirculating system banyak digunakan dalam industri. Sistem ini terdiri dari pompa, HE, dan cooling tower. Pompa akan meresirkulasikan air melalui HE, mengambil panasnya, lalu membuangnya di cooling tower dimana panas tersebut akan dibuang dari air dengan cara evaporasi. Dalam sistem ini, chemical akan lebih banyak digunakan karena komposisi air akan berubah saat evaporasi berlangsung, dimana konstituen korosi dan scaling akan lebih pekat (Gumilar, 2011). Air pendingin teruapkan sekitar 1\% water. Kehilangan air akibat penguapan ini harus dikompensasi oleh make up air pendingin.

Keuntungan menggunakan Open evaporative recirculating systems:

a. Jumlah kebutuhan air sedikit (make up).

b. Memungkinkan untuk mengontrol korosi.

Kerugian menggunakan Open evaporative recirculating systems:

a. Investasi (capital cost) lebih tinggi daripada once through.

b. Memerlukan cooling tower yang cukup besar.

c. System purge dan blowdown kemungkinan dapat mengakibatkan pencemaran lingkungan.

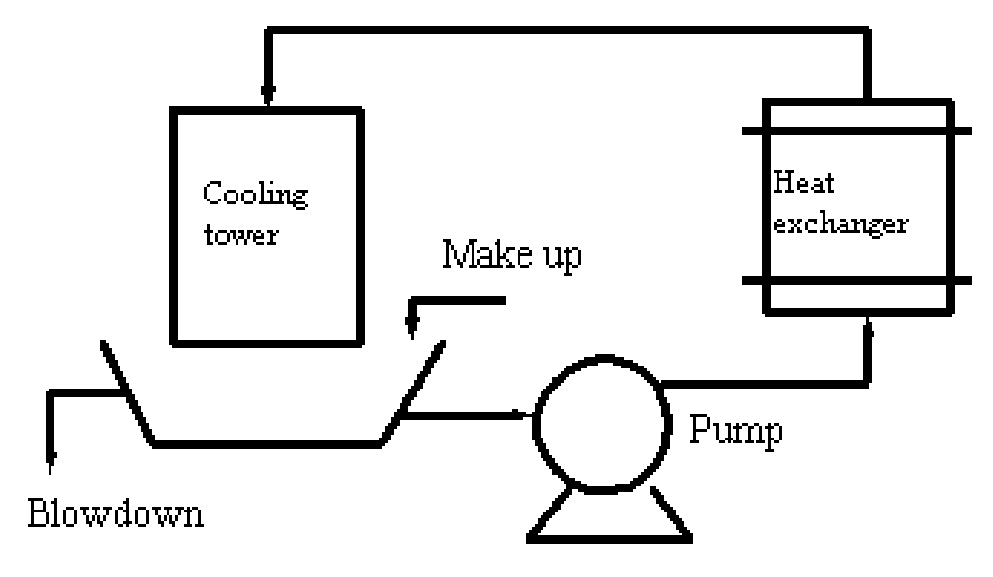

Gambar 1. Once Through System

\section{Sistem Siklus Tertutup}

Air pendingin utama pada PLTU asam-asam menggunakan siklus tertutup, di mana media air pendingin digunakan secara berulang-ulang. Akibat proses penyerapan panas di kondensor, temperatur air pendingin keluar kondensor akan naik. Karena air akan disirkulasikan kembali ke kondensor, maka air pendingin ini harus didinginkan terlebih dahulu di menara pendingin (cooling tower). Di dalam menara pendingin, air pendingin didinginkan oleh udara sehingga temperaturnya kembali turun dan siap disirkulasikan kembali kedalam kondensor. 


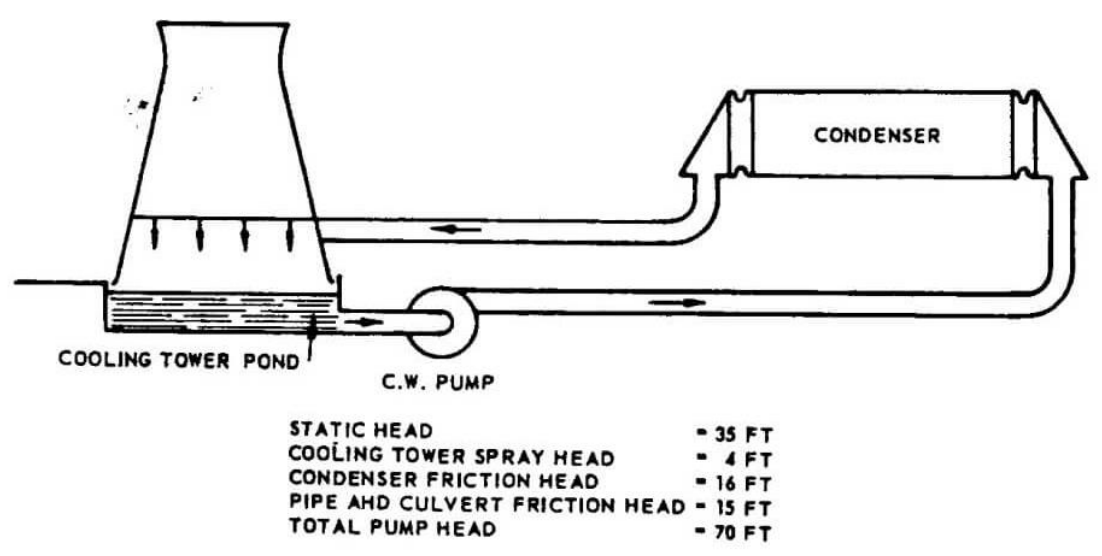

Gambar 2. Siklus Air Pendingin Cooling Tower

\section{Siklus Rankine}

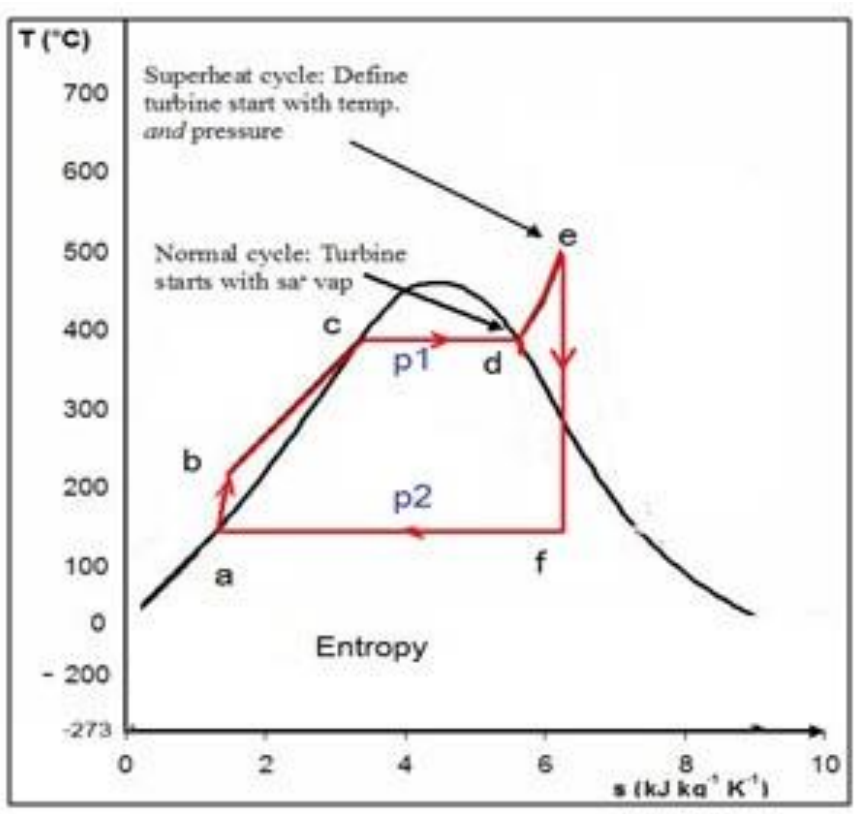

Gambar 3. Siklus Rankine Sederhana

a - b : Air dipompa dari tekanan P2 menjadi P1. Langkah ini adalah langkah kompresi isentropik, dan proses ini terjadi pada pompa air pengisi.

$\mathrm{b}-\mathrm{c}$ : Air bertekanan ini dinaikkan temperaturnya hingga mencapai titik didih. Terjadi di $L P$ heater, HP heater dan Economizer.

$c-d$ : Air berubah wujud menjadi uap jenuh. Langkah ini disebut vapourising (penguapan) dengan proses isobar isothermis, terjadi di boiler yaitu di wall tube (riser) dan steam drum.

$\mathrm{d}-\mathrm{e}$ : Uap dipanaskan lebih lanjut hingga uap mencapai temperatur kerjanya menjadi uap panas lanjut (superheated vapour). Langkah ini terjadi di superheater boiler dengan proses isobar.

e-f : Uap melakukan kerja sehingga tekanan dan temperaturnya turun. Langkah ini adalah langkah ekspansi isentropis, dan terjadi didalam turbin.

$\mathrm{f}-\mathrm{a}$ : Pembuangan panas laten uap sehingga berubah menjadi air kondensat. Langkah ini adalah isobar isothermis, dan terjadi didalam kondensor. 


\section{Perpindahan Panas}

Panas adalah salah satu bentuk energi yang dapat dipindahkan dari suatu tempat ke tempat lain, tetapi tidak dapat diciptakan atau dimusnahkan sama sekali. Dalam suatu proses, panas dapat mengakibatkan terjadinya kenaikan suhu suatu zat dan atau perubahan tekanan, reaksi kimia dan kelistrikan. Proses terjadinya perpindahan panas dapat dilakukan secara langsung, yaitu fluida yang panas akan bercampur secara langsung dengan fluida dingin tanpa adanya pemisah dan secara tidak langsung, yaitu bila diantara fluida panas dan fluida dingin tidak berhubungan langsung tetapi dipisahkan oleh sekat-sekat pemisah. (Cengel, 2006)

\section{Circulating Water Pump}

Circulating Water Pump atau biasa disebut dengan CWP adalah komponen PLTU pada sistem Cooling Tower yang berfungsi untuk memompakan air pendingin utama dari Cooling Tower menuju kondensor, air ini bertujuan untuk mengkondensasikan uap hasil ekstraksi turbin untuk diubah menjadi air kondensat kembali. Pada PLTU Pembangkitan Asam - Asam terdapat 2 pompa CWP untuk membangkitkan daya 65 MW. Berikut Gambar CWP yang terdapat pada PLTU Pembangkitan Asam - Asam.

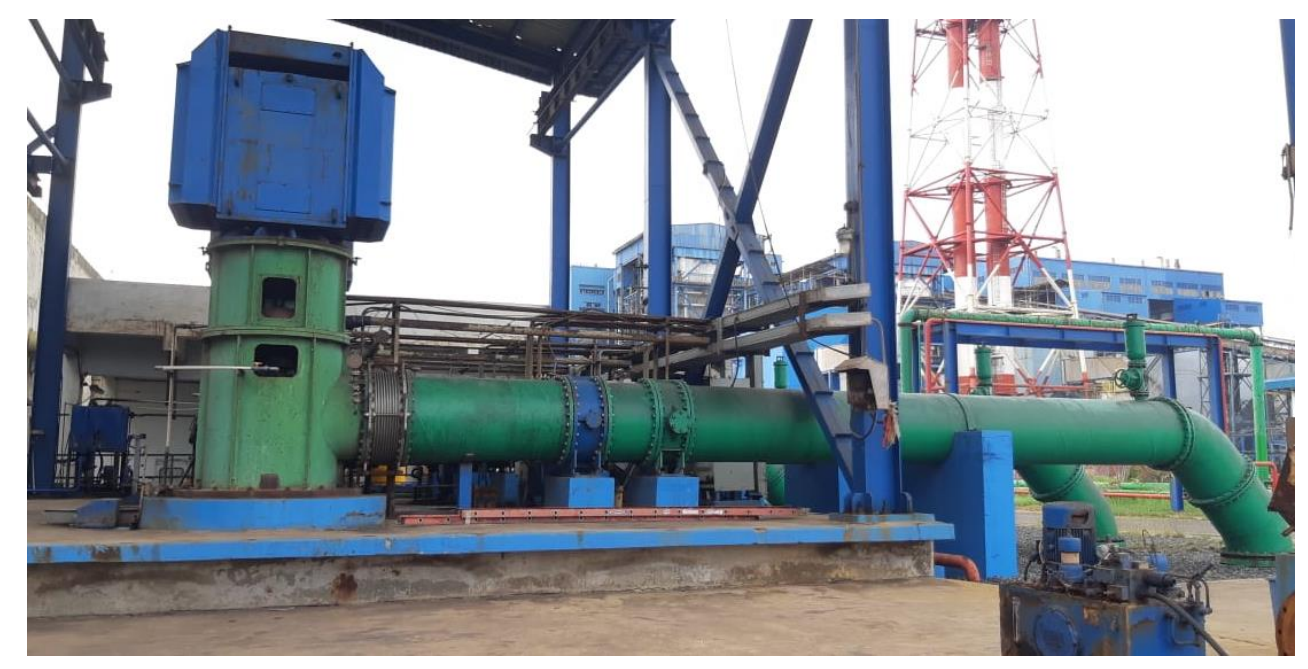

Gambar 4. CWP PLTU Asam-Asam

\section{METODE PENELITIAN}

1. Studi literatur

Pada tahap ini, teori-teori serta konsep-konsep penelitian yang telah dikembangkan sebelumnya dan ada hubungannya dengan masalah yang dihadapi di emukakan sebagai dasar menuju tahapan selanjutnya. Studi pustaka dilakukan dengan mempelajari teori-teori yang akan digunakan untuk mencapai tujuan penelitian yang hendak dicapai. Studi pustaka yang dilakukan mengenai PLTU, komponen cooling tower, kondensor, CWP serta cara analisis statistik. Studi pustaka ini diperoleh dari sumber beberapa buku maupun jurnal yang di dapat di internet.

\section{Pengumpulan data}

Pengumpulan data merupakan sebuah prosedur yang sistematik dan standar untuk memperoleh data yang di perlukan. Metode pengumpulan data yang di lakukan adalah dengan mengambil data yang ada di Computer Control 
Room Unit 4 PLTU Asam-Asam. Data-data yang diperlukan adalah parameter operasi dan turunan.

3. Pengolahan data

Data yang telah didapat kemudian dikumpulkan agar dapat dilakukan analisis dalam penelitian ini.

4. Pengambilan kesimpulan

Dari hasil analisis data yang didapat selanjutnya dapat diambil kesimpulan mengenai pola operasi CWP manakah yang paling baik untuk membangkitkan daya optimal 65 MW pada PLTU PT. PLN (PERSERO) Sektor Pembangkitan Asam - Asam unit 4.

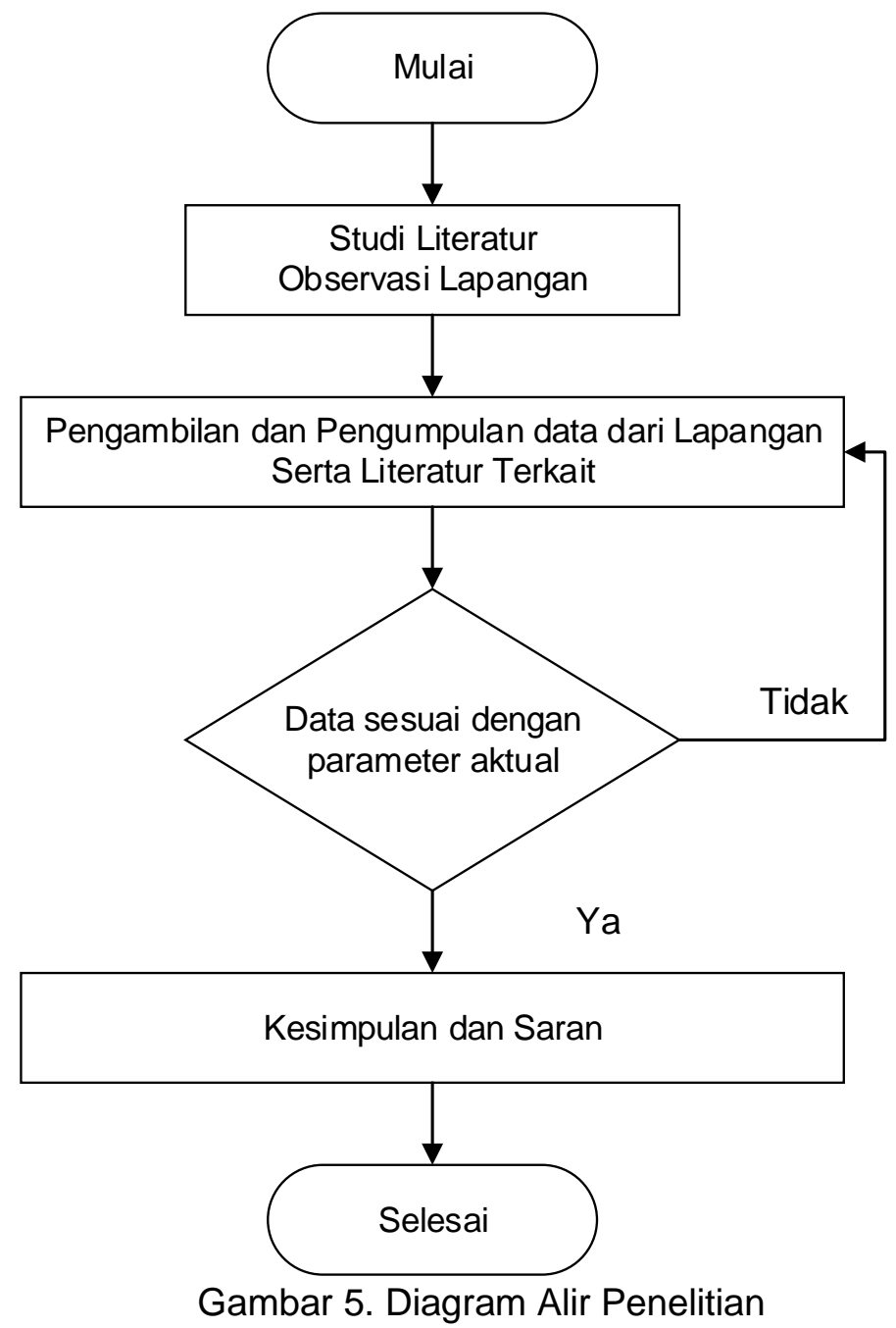




\section{HASIL DAN PEMBAHASAN}

Dalam pengoperasian 1 CWP dan 2 CWP, dapat diamati parameter sebagai berikut:

\section{Tara Kalor (NPHR)}

Pada Gambar 6 di bawah ini, dapat dilihat besaran tara kalor netto per hari. Tara kalor dapat dihitung dengan persamaan di bawah ini.

$$
\begin{aligned}
N P H R & =\frac{\left.\dot{m}_{b b} \cdot \mathrm{Cal}\right|_{b b}}{P_{\text {net }}} \\
N P H R & =\frac{48,5 \cdot 4200}{58} \\
& =3508 \\
N P H R & =\text { Tara kalor Netto }(\mathrm{kCal} / \mathrm{kWh}) \\
\dot{m}_{b b} & =\text { Laju massa batubara }(\mathrm{Ton} / \mathrm{h}) \\
C a l_{b b} & =\text { Kalori batubara }(\mathrm{kCal} / \mathrm{kg}) \\
P_{\text {net }} & =\text { Daya Netto }(\mathrm{MW})
\end{aligned}
$$

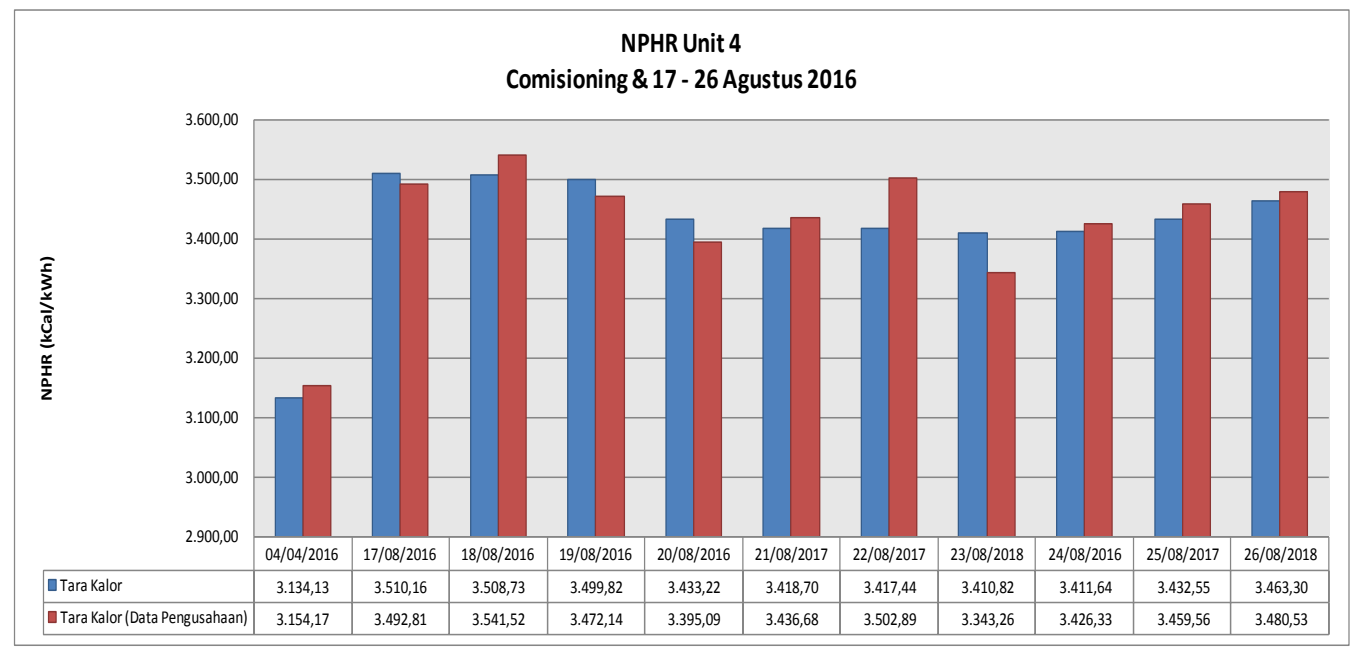

Gambar 6. Tara Kalor Netto Unit 4

Dapat dilihat ada penurunan pada tara kalor antara pengoperasian satu CWP dengan dua CWP. Perbedaan tara kalor rata-rata antara dua CWP dan satu CWP adalah sebesar $\pm 80 \mathrm{kCal} / \mathrm{kWh}$.

Rekomendasi : 1 CWP

\section{Efisiensi Thermal}

Untuk perubahan pada efisiensi thermal, dapat dilihat pada Gambar 7.

$$
\begin{aligned}
\eta_{\text {th }} & =\frac{3.600}{4,1868 \cdot N P H R} \\
\eta_{\text {th }} & =\frac{3.600}{4,1868 \cdot 3508} \\
& =24 \% \\
\eta_{\text {th }} & =\text { Efisiensi thermal }(\%)
\end{aligned}
$$




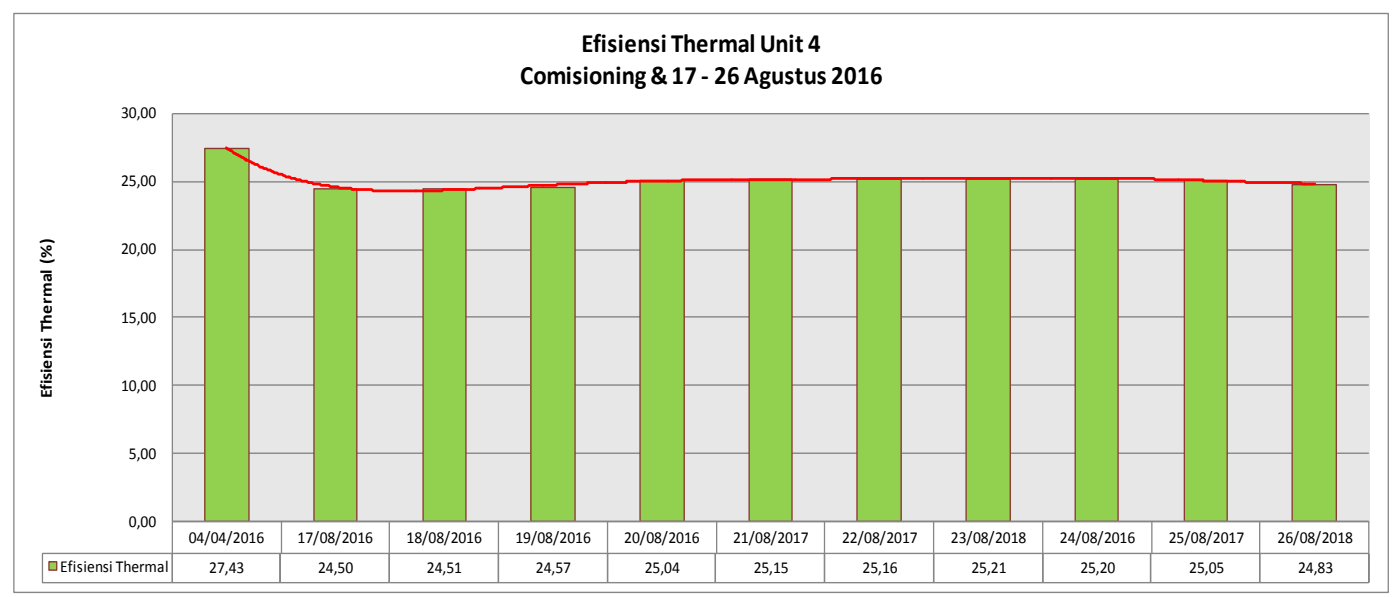

Gambar 7. Efisiensi Thermal Unit 4

Besaran selisih efisiensi thermal antara dua CWP dan satu CWP rata-rata adalah sebesar $\pm 0,5 \%$.

Rekomendasi: 1 CWP

\section{Daya Netto dan PS}

Turunnya NPHR dari pengoperasian satu CWP lebih banyak disebabkan oleh turunnya Pemakaian Sendiri (PS) dan meningkatnya Daya Netto, walaupun turunnya vakum kondensor mengakibatkan banyaknya flow Main Steam. Untuk perubahan pada Daya Netto dan PS dapat dilihat pada Gambar 8.

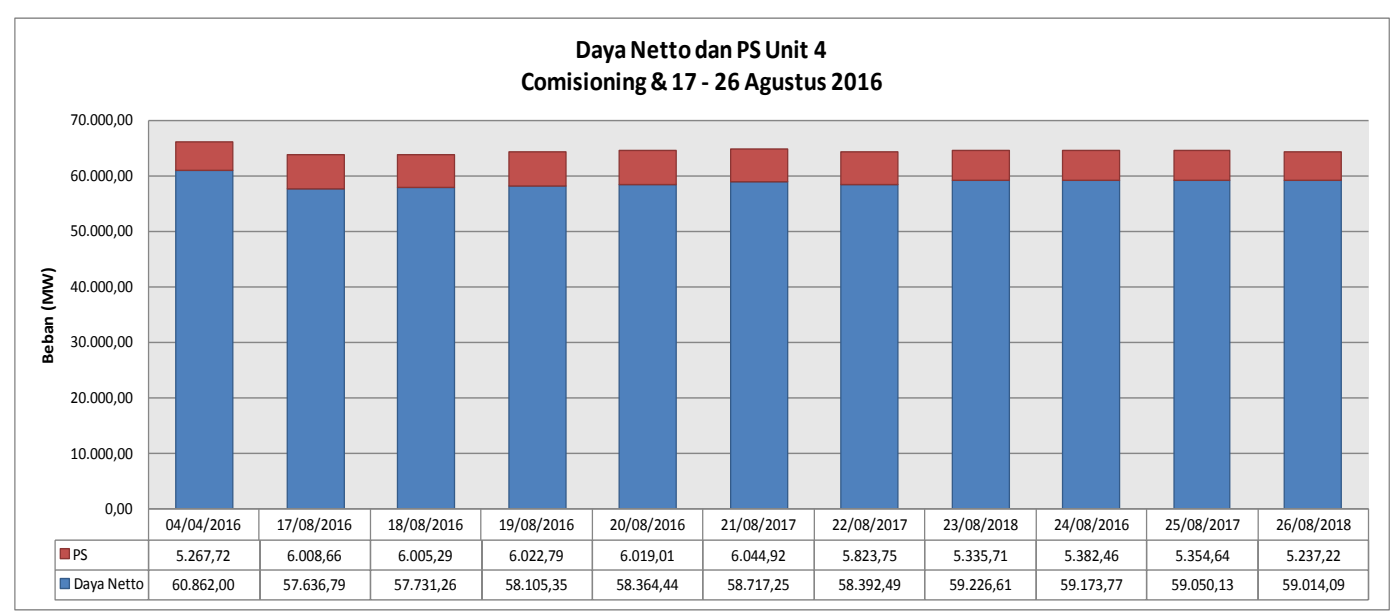

Gambar 8. Daya Netto dan PS Unit 4

Dengan menggunakan satu CWP, besaran PS yang dapat dihemat ratarata adalah sebesar $\pm 600 \mathrm{~kW}$; sehingga rata-rata PS turun dari $\pm 6.000 \mathrm{~kW}$ menjadi $\pm 5.400 \mathrm{~kW}$.

Rekomendasi: 1 CWP

\section{Vacuum Pressure dan Main Steam Flow}

Turunnya flow Cooling Water secara langsung mempengaruhi vakuum kondesor, di mana pada pengoperasian 1 CWP rata-rata vakuum kondensor sebesar -0,800 barg atau 0,213 bar absolute (bara), dan pada 2 CWP rata-rata 0,835 barg atau 0,178 bara. Turunnya vakuum kondensor mempengaruhi efisiensi turbin, sehingga untuk meningkatkan daya yang sama memerlukan steam flow yang lebih besar. Lebih jelasnya dapat dilihat pada Gambar 9. 


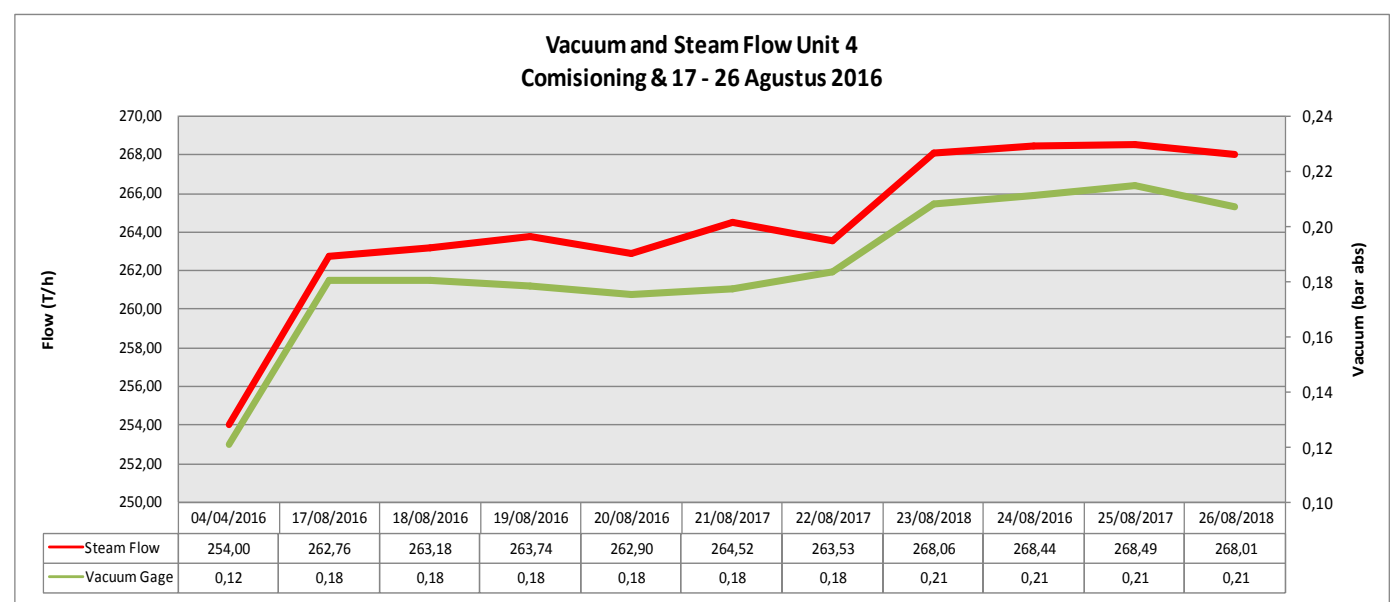

Gambar 9. Vacuum and Steam Flow Unit 4 untuk beban 64 - 65 MW

Rekomendasi: 2 CWP

Naiknya Steam Flow sebesar 5 hingga 6 T/h untuk membangkitkan daya turbin yang sama, sehingga memerlukan batu bara yang lebih banyak. Namun, besarnya kalori yang diperlukan masih lebih kecil dibandingkan PS yang dihemat, sehingga tara kalor pada 1 CWP bisa lebih rendah.

\section{Turbine Exhaust dan Feedwater Heater Extraction Flow}

Turunnya vakum kondensor mengakibatkan perubahan pada Main Steam Flow dan pada akhirnya menaikkan tonase Turbin Exhaust menuju Kondensor. Besaran turbin exhaust maupun masing-masing ekstraksi dihitung berdasarkan energi balance Rankine Cycle Unit 4. Unit 4 PLTU Asam Asam memiliki 6 ekstraksi, yaitu $2 \mathrm{HPH}, 1$ Deaerator dan $3 \mathrm{LPH}$. Besaran masing-masing ekstraksi dapat dilihat pada Gambar 10.

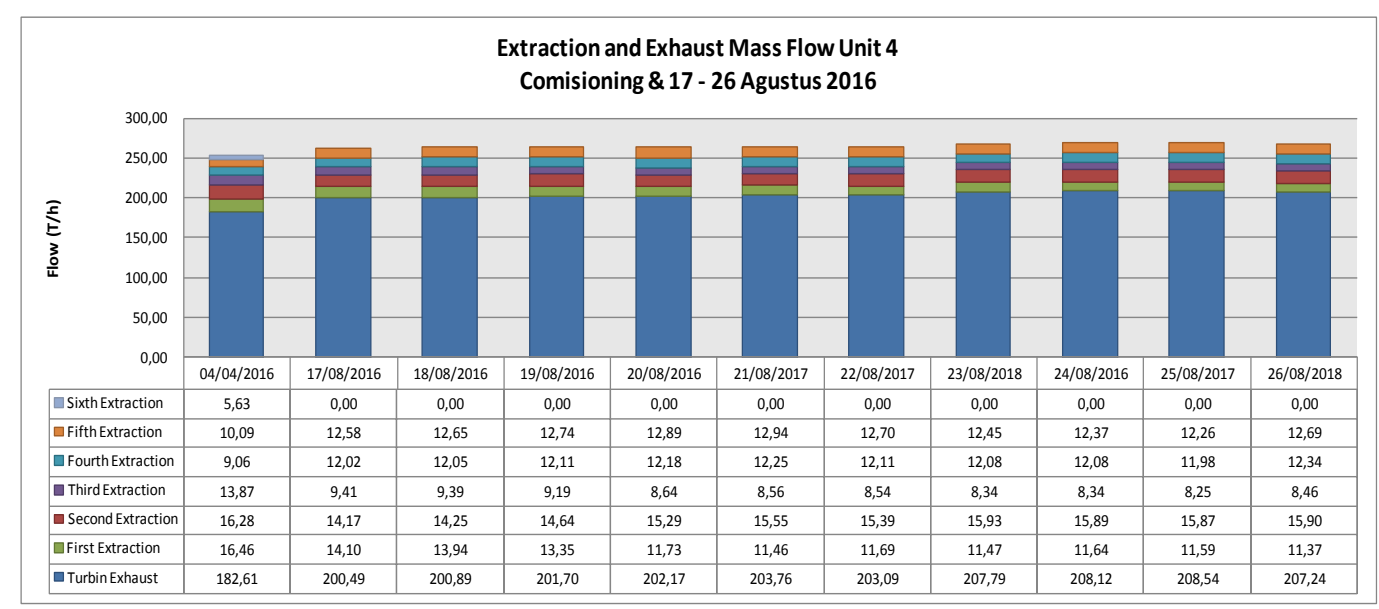

Gambar 10. Flow Ekstraksi dan Exhaust Turbin Unit 4

Rekomendasi: 2 CWP

Rata-rata flow Main Steam dengan dua CWP adalah \pm 263 Ton $/ \mathrm{h}$, sedangkan dengan satu CWP naik menjadi sekitar \pm 268 Ton/h. Naiknya Main Steam Flow disebabkan oleh turunnya efisiensi turbin akibat turunnya vakum. Sehingga, untuk membangkitkan daya yang sama, turbin mengkonsumsi lebih banyak flow Main Steam. 


\section{Efisiensi Isentropik dan Aktual Turbin}

Dengan turunnya vakum kondensor, efisiensi turbin baik isentropik maupun aktual menurun. Efisiensi turbin isentropik adalah perbandingan antara daya mampu dengan daya shaft turbin (Brake Horsepower). Sementara efisiensi aktual turbin adalah perbandingan antara daya mampu dengan Total Steam Enthalpy (memperhitungkan losses enthalpy di kondensor). Besaran efisiensi isentropik maupun aktual dapat dilihat pada Gambar 11, sementara untuk perhitungannya menggunakan persamaan berikut :

$$
\begin{array}{ll}
\eta_{i} & =\frac{P_{g}}{B H P_{T}} \\
\eta_{i} & =\frac{63.848 \times 100 \%}{77.436} \\
& =82,45 \% \\
\eta_{T} & =\frac{P_{g}}{h_{\text {tot }}} \\
\eta_{T} & =\frac{63.848 \times 100 \%}{187.769} \\
& =34 \% \\
\eta_{i} & =\text { Efisiensi Isentropik (\%) } \\
\eta_{T} & =\text { Efisiensi Aktual Turbin (\%) } \\
P g & =\text { Daya Mampu (kW) } \\
B H P_{T} & =\text { Daya Shaft Turbin (kW) } \\
h_{\text {tot }} & =\text { Total Steam Enthalpy (kW) }
\end{array}
$$

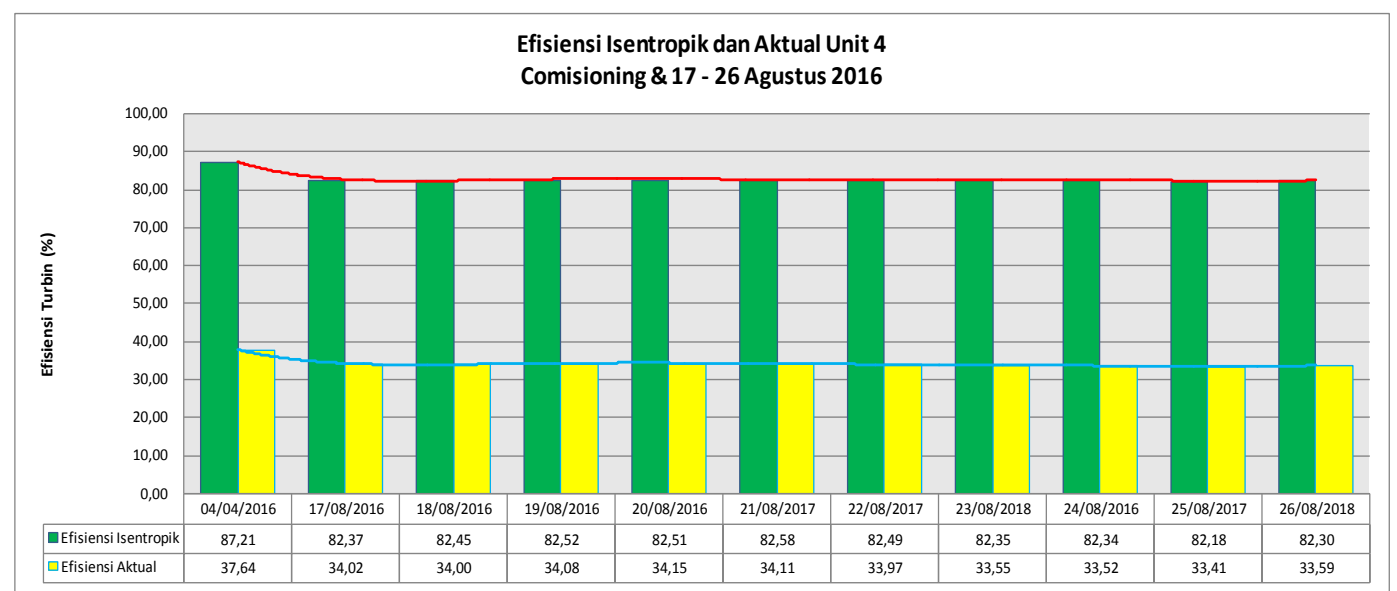

Gambar 11. Efisiensi Isentropik dan Aktual Unit 4

Rekomendasi: 2 CWP

Pada saat pengoperasian satu CWP, efisiensi isentropik turbin turun sebesar $\pm 0,3 \%$, sementara efisiensi aktual turbin turun sebesar $\pm 0,5 \%$. Jadi untuk menghindari turunnya efisiensi isentropik turbin yang berdampak pada penilaian kinerja pembangkit perlu pengoperasian $2 \mathrm{CWP}$.

\section{Cleanliness Factor dan Efektifitas Kondensor}

Untuk mengetahui pengaruh pola operasi CWP terhadap kondensor, perlu diperhitungkan beberapa parameter turunan untuk kondensor, seperti faktor 
kebersihan tube kondensor dan efektifitas kondensor. Besaran faktor kebersihan dan efektifitas kondensor dapat dihitung dengan persamaan di bawah ini.

$$
\begin{aligned}
C F & =\frac{U}{U c d} \\
C F & =\frac{1257 \times 100 \%}{3630} \\
& =34,64 \% \\
\varepsilon & =\frac{C_{c / h}\left(T_{c o} / h^{-}-T_{c i} / h o\right.}{C_{\min }\left(T_{h i}-T_{c i}\right)} \\
C F & =\text { Cleanliness Factor }(\%) \\
\varepsilon & =\text { Efektifitas Kondensor }(\%) \\
U & =\text { Overall Heat Transfer Coefficient aktual }\left(\mathrm{W} / \mathrm{m}^{2} \cdot \operatorname{deg} \mathrm{C}\right) \\
U c d & =\text { Overall Heat Transfer Coefficient desain }\left(\mathrm{W} / \mathrm{m}^{2} \cdot \operatorname{deg} \mathrm{C}\right) \\
C & =\text { Kapasitas Panas; } \mathrm{c}=\text { cold, } \mathrm{h}=\text { hot }(\mathrm{kJ} / \mathrm{deg} \mathrm{C} \cdot \mathrm{s}) \\
T & =\text { Temperatur; } \mathrm{i}=\text { inlet, } \mathrm{o}=\text { outlet }(\mathrm{deg} \mathrm{C})
\end{aligned}
$$

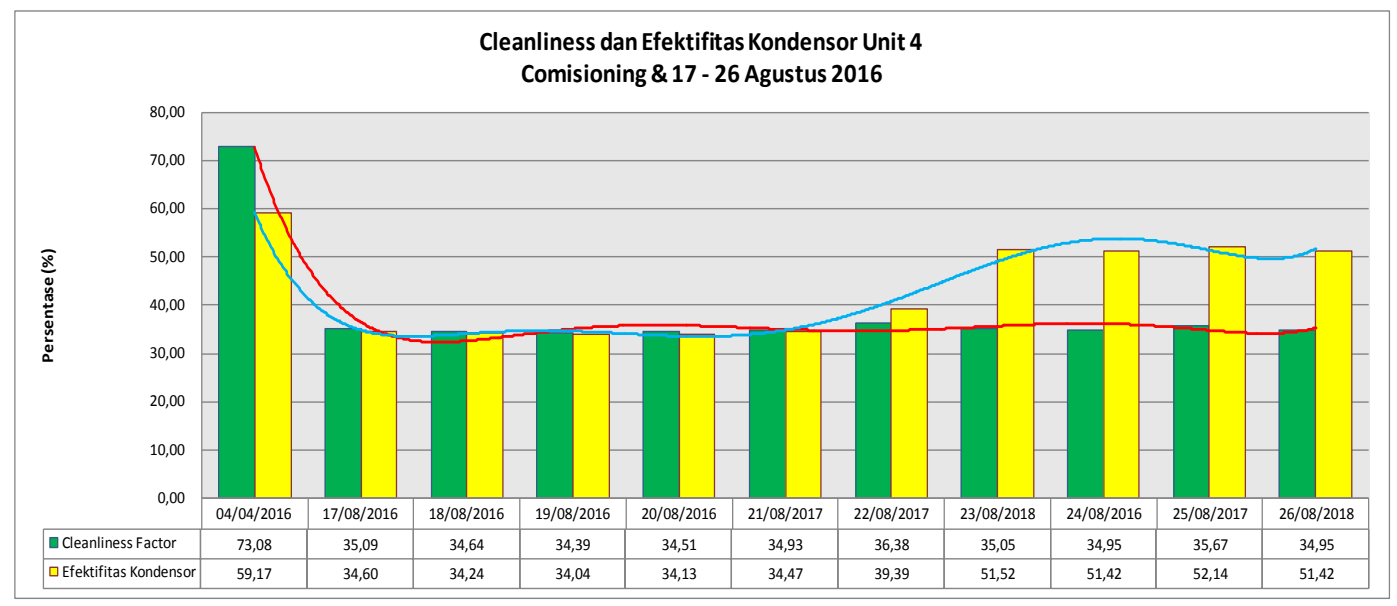

Gambar 12. Cleanliness dan Efektifitas Kondensor

Dari Gambar 12, dapat dilihat tidak ada perubahan pada tingkat kebersihan tube, tetapi nilai efektifitas kondensor meningkat.

Rekomendasi: 1 CWP

\section{Thermal Stress Tube Condensor}

Karena adanya perbedaan temperatur yang tinggi antara exhaust steam dengan tube kondensor, maka tegangan thermal dan tekanan thermal yang terjadi pada tube kondensor juga perlu diperhatikan. Tegangan thermal yang terjadi tidak boleh melebihi ultimate tensile strength material tube. Besar strength material tube (Titanium grade 3) adalah $440 \mathrm{MPa}$. Untuk operasi normal, perlu diambil batas safety factor sebesar 5,0, sehingga batasan tegangan thermal adalah $88 \mathrm{MPa}$. Besaran tegangan thermal dan perhitungannya dapat dilihat di bawah ini.

$$
\begin{aligned}
\sigma_{d T m} & =E \cdot \alpha \cdot \Delta T_{\max } \\
\sigma_{d T m} & =8,4 \times 105 \times 22,38 \div 1000 \\
& =19,73 \mathrm{Mpa} \\
\sigma_{d T m} & =\text { Tegangan Thermal (MPa) }
\end{aligned}
$$


$E \quad=$ Modulus Elastisitas Material $(105 \mathrm{GPa})$

$\alpha=$ Koefisien Ekspansi Material $\left(1 \cdot 10^{-6} \mathrm{~m} / \mathrm{m} \cdot \operatorname{deg} \mathrm{C}\right)$

$\Delta T_{\max }=$ Selisih Temperatur Tertinggi (degC)

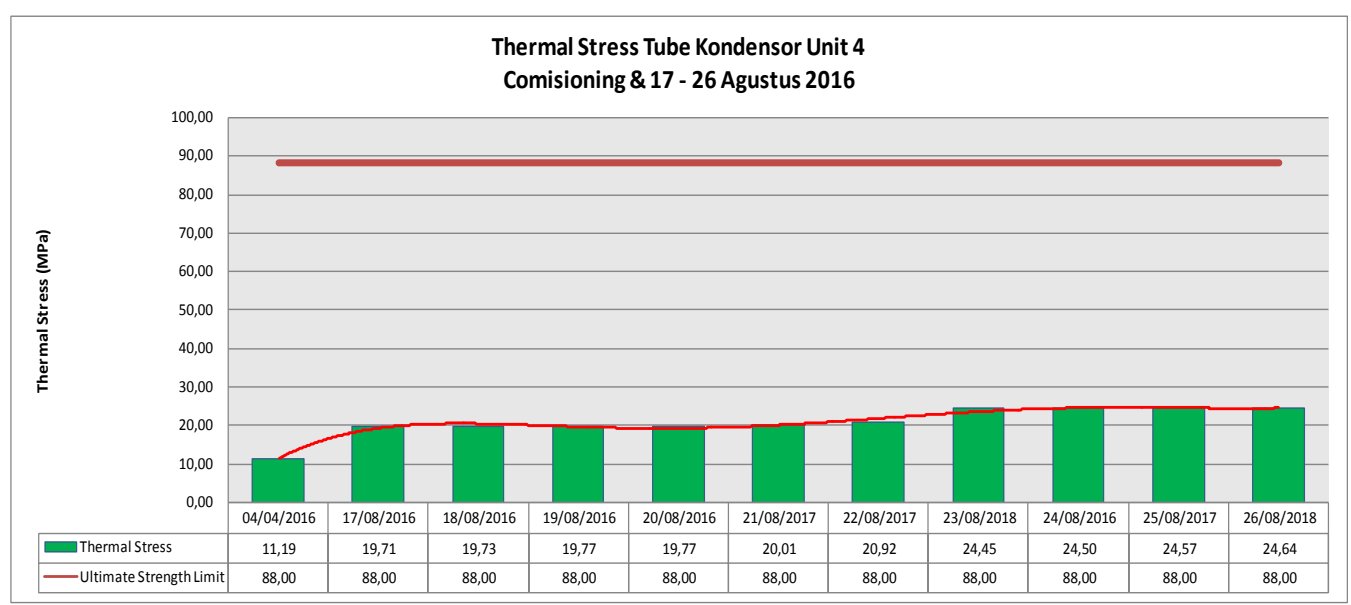

Rekomendasi: 2 CWP

Gambar 13. Thermal Stress pada Kondensor

Nilai tegangan thermal tube kondensor baik pada satu maupun dua CWP, masih berada jauh di bawah batas safety strength material, yaitu $88 \mathrm{MPa}$ yang ditunjukkan oleh garis lurus berwarna merah. Sehingga dapat disimpulkan bahwa pada pengoperasian satu CWP dengan beda temperatur tertinggi (27,93 degC), sangat kecil kemungkinan kegagalan akibat tegangan thermal.

\section{Thermal Force Tube Kondensor}

Selain memperhitungkan tegangan thermal, gaya thermal juga perlu diperhatikan. Gaya adalah tekanan dikalikan luas penampang. Gaya thermal terjadi akibat ekspansi tube yang tidak bebas/tertahan pada suaian pemasangannya. Besaran gaya thermal dan perhitungannya dapat dilihat di bawah ini.

$$
\begin{aligned}
F_{d T m} & =\sigma_{d T m} \cdot A_{c s} \\
F_{d T m} & =19,73 \times 301 \\
& =5.951 \mathrm{~N} \\
F_{d T m} & =\text { Gaya Thermal }(\mathrm{N}) \\
A_{c s} & =\text { Luas Penampang Tube, satuan maupun total }\left(\mathrm{m}^{2}\right)
\end{aligned}
$$




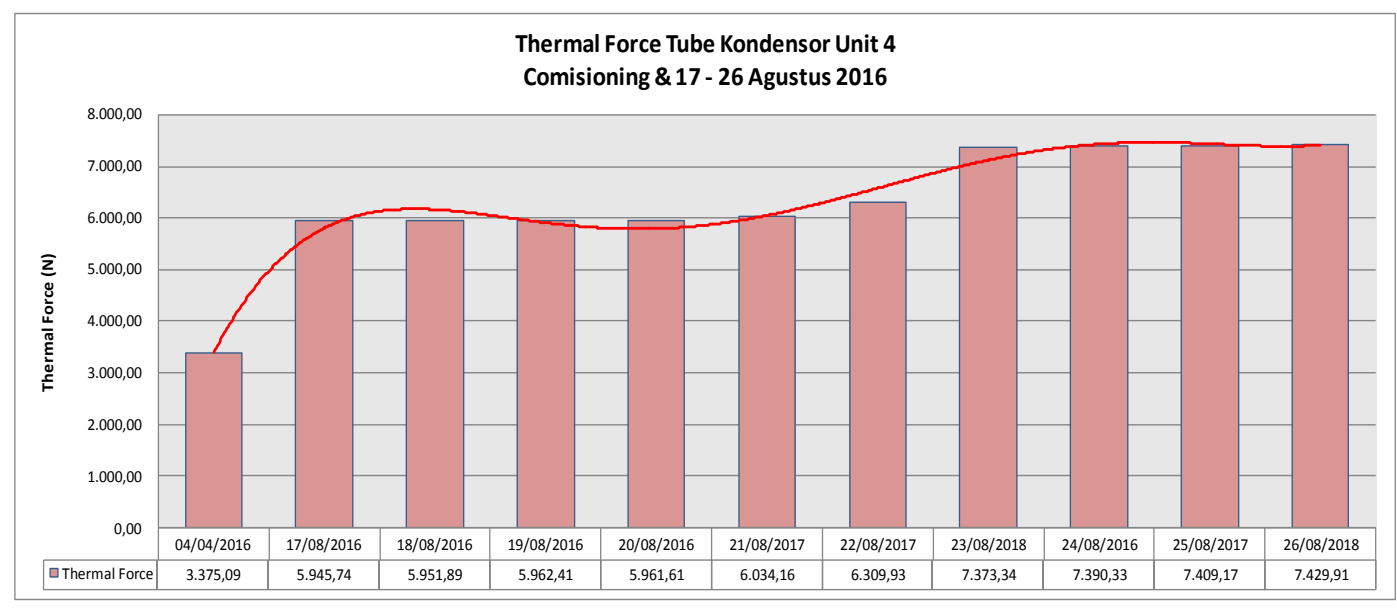

Gambar 14. Thermal Force pada Kondensor

Rekomendasi: 2 CWP

Seiring dengan kenaikan tegangan thermal, gaya thermal juga ikut naik. Tetapi karena tegangan thermal masih di bawah batas safety, tentunya gaya thermal juga masih aman. Sehingga dapat disimpulkan untuk tegangan maupun gaya thermal pada kondensor masih aman baik untuk dua maupun satu CWP.

\section{CWP Current}

Pada peralatan CWP, yang perlu kita perhatikan adalah rata-rata arus CWP. Arus rated desain CWP adalah 83,70 A. Data arus CWP aktual yang diambil adalah rata-rata per hari.

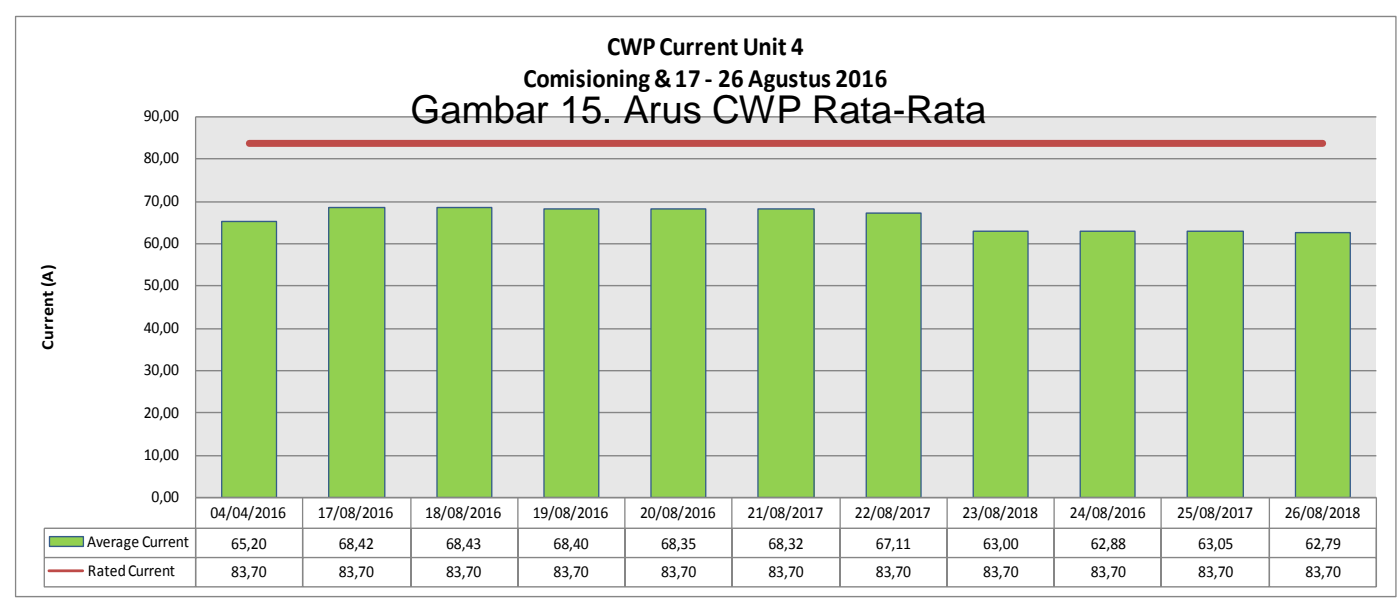

Rekomendasi: 1 CWP

Pada pengoperasian satu CWP, arus CWP cenderung turun sebesar 4-5 A. Untuk Unit 4, karakteristik ampere masing-masing CWP, CWP 4A (67 A) menggunakan arus lebih rendah daripada CWP 4B (69 A); dan pada pola operasi satu CWP, CWP yang digunakan adalah CWP 4A (63-64 A). Kemungkinan besar, penurunan arus CWP ini disebabkan oleh berkurangnya kecepatan aliran dalam pipa tunnel, sehingga besarnya losses akibat gesekan aliran juga berkurang secara eksponensial. Sehingga, dapat disimpulkan bahwa konsumsi arus CWP pada kedua pola operasi masih berada di bawah rated desain. Selain itu, CWP 4A memang mengkonsumsi lebih sedikit daya listrik dibandingkan CWP 4B. 


\section{Degree of Difficulty dan Liquid-Gas Ratio Cooling Tower}

Pada Cooling Tower, ada 5 parameter turunan yang dibahas pada analisa ini, antara lain Degree of Difficulty, Liquid-Gas Ratio (L/G Ratio), Efektifitas, Temperature Range dan Temperature Approach. Untuk membandingkan baik tidaknya nilai Degree of Difficulty, sebaiknya dibandingkan dengan karakteristik Cooling Tower $(K a V / L)$. Namun, karena keterbatasan data, nilai yang dipakai sebagai pembanding adalah data komisioning. Besarnya Degree of Difficulty dapat dilihat dan diformulasikan sebagai berikut.

$$
\begin{aligned}
N T U & =\frac{\Delta T(F)}{4} \sum \frac{1}{h_{w}-h_{a}} \\
N T U & =\frac{28,97}{4} \times \frac{1}{19,54}+\frac{1}{23,33}+\frac{1}{25,86}+\frac{1}{29,65} \\
& =1,21 \\
N T U & =\text { Degree of Difficulty (dimensionless) } \\
\Delta T(F) & =\text { Kenaikan Temperatur Cooling Water (degF) } \\
h_{w} & =\text { Enthalpy Cooling Water (Btu/lbm) } \\
h a & =\text { Enthalpy udara pendingin (Btu/lbm) }
\end{aligned}
$$

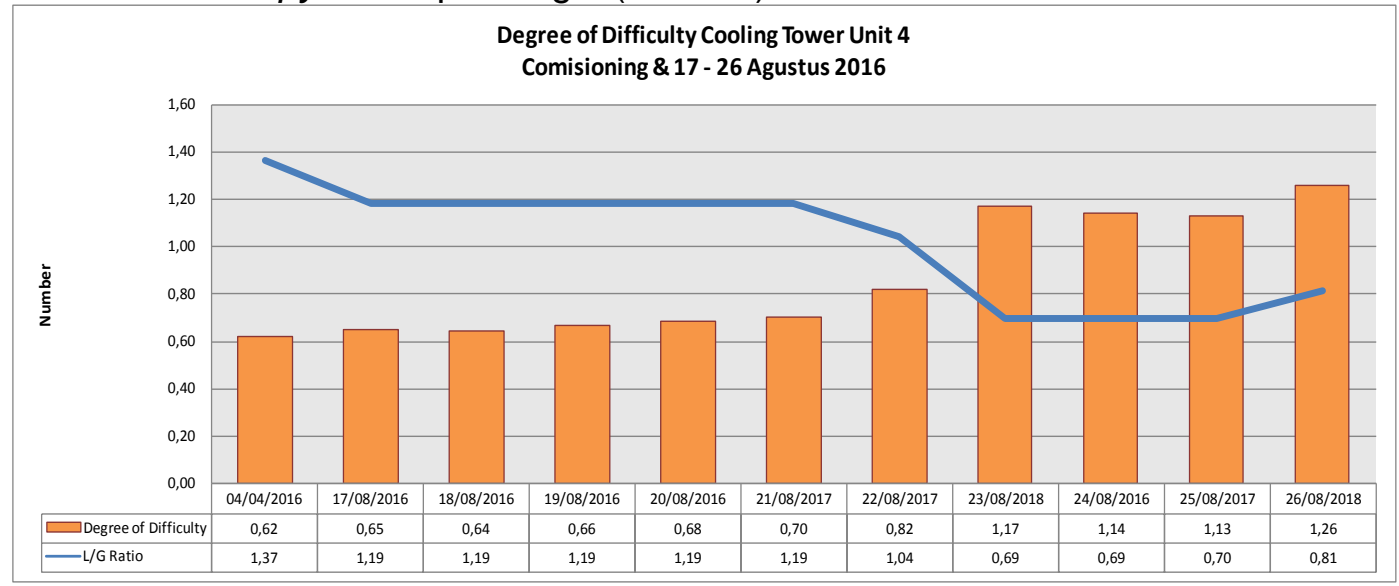

Gambar 16. Degree of Difficulty

Rekomendasi : 2 CWP

Dapat dilihat pada operasi 1 CWP, ada penurunan pada Liquid-Gas Ratio dan kenaikan pada Degree of Difficulty (DoD). Parameter DoD harus di bawah nilai karakteristik Cooling Tower (KaV/L), karena menandakan nilai desain Cooling Tower. Namun, karena tidak ada data nilai karakteristik, DoD aktual akan dibandingkan dengan DoD komisioning, sehingga dari Gambar 16 dapat dilihat bahwa pola operasi 2 CWP lebih baik.

\section{Temperature Range dan Temperature Approach Cooling Tower}

Selain kedua perbandingan tersebut, dua parameter lainnya adalah Temperature Range dan Temperature Approach. Temperature Range adalah penurunan temperatur air pendingin, sedangkan Temperature Approach adalah selisih temperatur antara temperatur bola basah udara pendingin dengan temperatur cold basin. Temperature Approach mengGambarkan kinerja cooling tower, semakin kecil maka semakin baik; sementara Temperature Range mengGambarkan besarnya beban panas yang harus didinginkan cooling tower. Namun, keduanya tidak langsung mengGambarkan kinerja cooling tower, karena tidak memperhitungkan flow. Besar masing-masing parameter dapat diformulasikan dan diGambarkan sebagai berikut. 


$$
\begin{array}{ll}
\Delta T & =\text { Tcwo-Tcwi } \\
T_{\text {app }} & =\text { Tcwi-Twb } \\
\Delta T & =\text { Temperature Range (degC) } \\
T_{\text {app }} & =\text { Temperature Approach (degC) }
\end{array}
$$

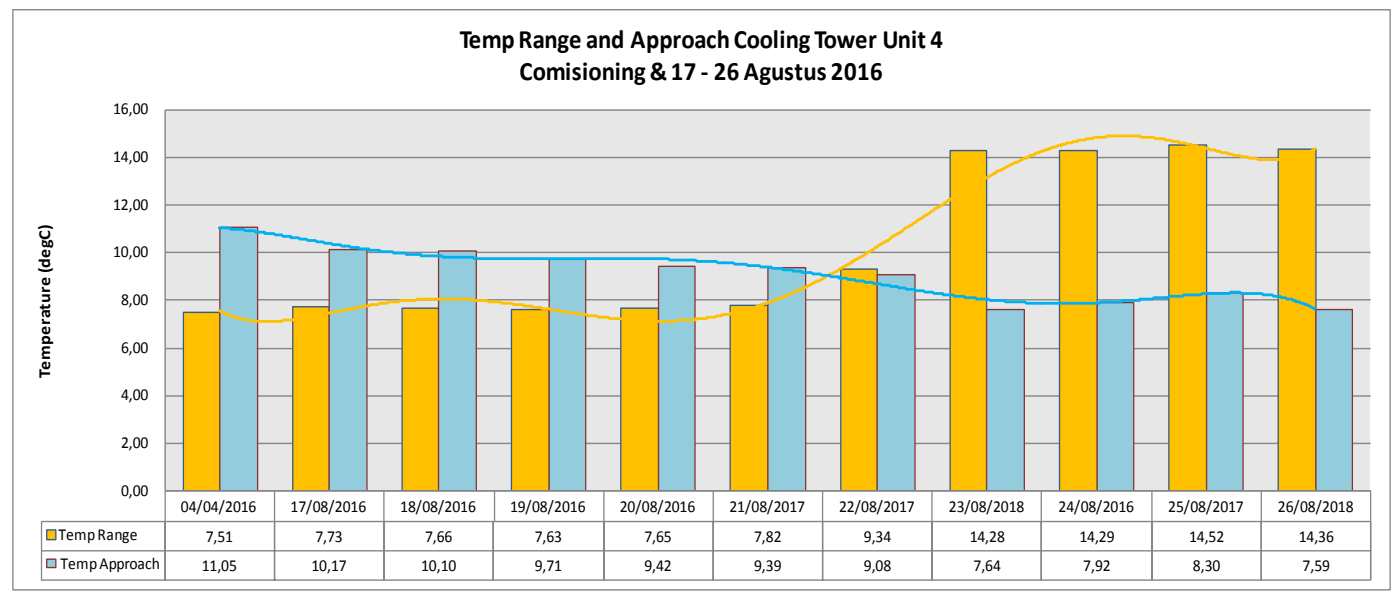

Gambar 17. Temperature Range dan Approach Cooling Tower

\section{Rekomendasi : 1 CWP}

Temperatur range naik pada pengoperasian 1 CWP namun tidak mengGambarkan kinerja cooling tower, pada data diatas terlihat temperatur approach turun pada $1 \mathrm{CWP}$ sehingga direkomendasikan pengoperasian $1 \mathrm{CWP}$ karena semakin kecil temperatur approach semakin baik.

\section{Water Consumption Untuk Cooling Tower}

Parameter cooling tower terakhir yang akan dikaji adalah konsumsi cooling water tiap pola operasi. Air pada cold basin cooling tower harus selalu di-makeup karena ada losses-losses air pada proses evaporasi. Selain evaporasi, ada juga losses akibat blowdown dan drift. Jadi, konsumsi cooling water adalah akibat ketiga losses tersebut. Besarnya losses dan formulasinya adalah sebagai berikut.

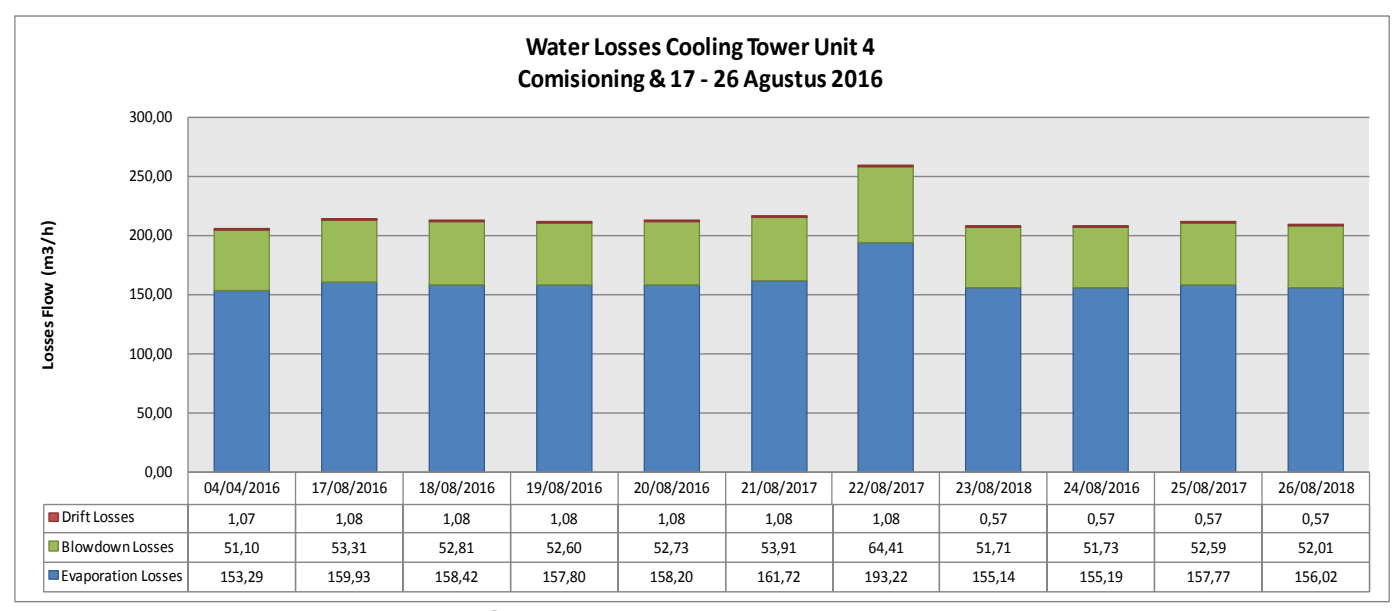

Gambar 18. Water Losses

Rekomendasi : Baik untuk keduanya 


\section{NPSHA Condensate Extraction Pump}

Net Positive Suction Head (NPSH) adalah head pada sisi hisap pompa yang diperlukan untuk menghindari turunnya tekanan uap air pada impeler pompa di bawah tekanan uap air pada temperatur tersebut. NPSH ada dua macam, yaitu NPSH yang diperlukan (NPSHR) dan NPSH yang disediakan (NPSHA). NPSHA harus lebih besar daripada NPSHR, untuk menghindari kavitasi. NPSHR CEP Unit 4 adalah $1,3 \mathrm{~m}$, jadi besarnya NPSHA yang disediakan oleh sistem harus di atas 1,3 m. Pada kajian ini, akan diGambarkan dan diformulasikan besarnya NPSHA pada tiap harinya (untuk pompa vertikal dengan level elevasi hisap di atas level discharge).

$N P S H A=H p a+H z s-H p v-H v s$

$$
\begin{aligned}
\text { NPSHA } & =1,25+1,62-1,22-0,01=1,63 \mathrm{~m} \\
\text { NPSHA } & =\text { Net Positive Suction Head Available }(\mathrm{m}) \\
H p a & =\text { Hotwell Static Head }(\mathrm{m}) \\
H z s & =\text { Suction Elevation Head }(\mathrm{m}) \\
H p v & =\text { Vapor Pressure Head }(\mathrm{m}) \\
H v s & =\text { Suction Dynamic Head }(\mathrm{m})
\end{aligned}
$$

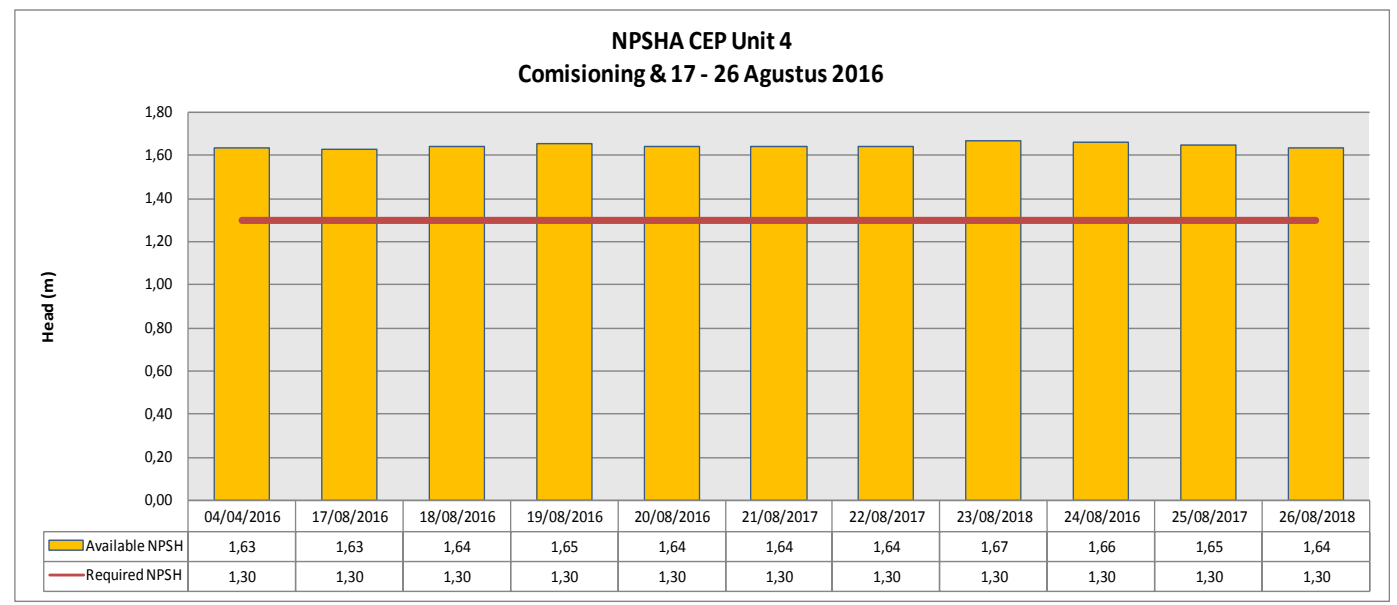

\section{Gambar 19. NPSHA CEP}

Rekomendasi : Baik untuk keduanya

Dari Gambar 19 di atas, dapat dilihat bahwa selama level hotwell kondensor tidak turun lebih dari 300 mm, maka tidak akan ada kavitasi pada impeller pompa.

\section{Kajian Risiko Operasi 1 CWP}

Hal lain yang perlu digaris bawahi adalah keandalan pengoperasian. Pada pola operasi 2 CWP, jika terjadi trip pada pompa, unit masih bisa derating dan mempersiapkan pengoperasian CWP kedua kembali. Namun, jika trip pada pola operasi $1 \mathrm{CWP}$, proteksi akan bekerja dan unit akan trip. Trip dan deratingnya unit sama-sama berdampak pada nilai EAF dan CF, tetapi tripnya unit berat dampak buruknya lebih besar daripada derating, karena start-up unit memakan waktu hingga 3 jam. Oleh karena itu, diperlukan kajian risiko untuk perbandingan pola pengoperasian CWP.

Rekomendasi: 2 CWP 


\section{KESIMPULAN}

Berdasarkan dari analisis dan pembahasan hasil penelitian maka untuk mengambil keputusan seperti apa pola operasi yang terbaik, perlu disimpulkan masing-masing rekomendasi yang telah dibahas diatas, kemudian dipilih yang terbaik dari yang paling banyak poinnya untuk ditarik kesimpulan. Dari pembahasan analisis terlihat bahwa pengoperasian 2 CWP lebih baik daripada 1 CWP karena tingkat resiko 2 CWP lebih rendah bila dibandingkan dengan nilai kerugian ketika menggunakan $1 \mathrm{CWP}$.

\section{DAFTAR PUSTAKA}

ASME PTC 6, 2004. Steam Turbines.

ASME PTC 23, 2003. Atmospheric Water Cooling Equipment.

Gumilar, 2011. Sistem Air Pendingin.

Incropera, 2007. Heat Transfer \& Fluid Book Frank Incropera Fundamental Sofheat \& Mass Transfer.

Perry's Chemical Engineer Handbook 1999.

PT PLN PERSERO, 2018. Perhitungan NKO Korporat.

Y. A. Çengel and M. A. Boles. 1994. Thermodynamics: An Engineering Approach, 5th ed, McGraw-Hill. 